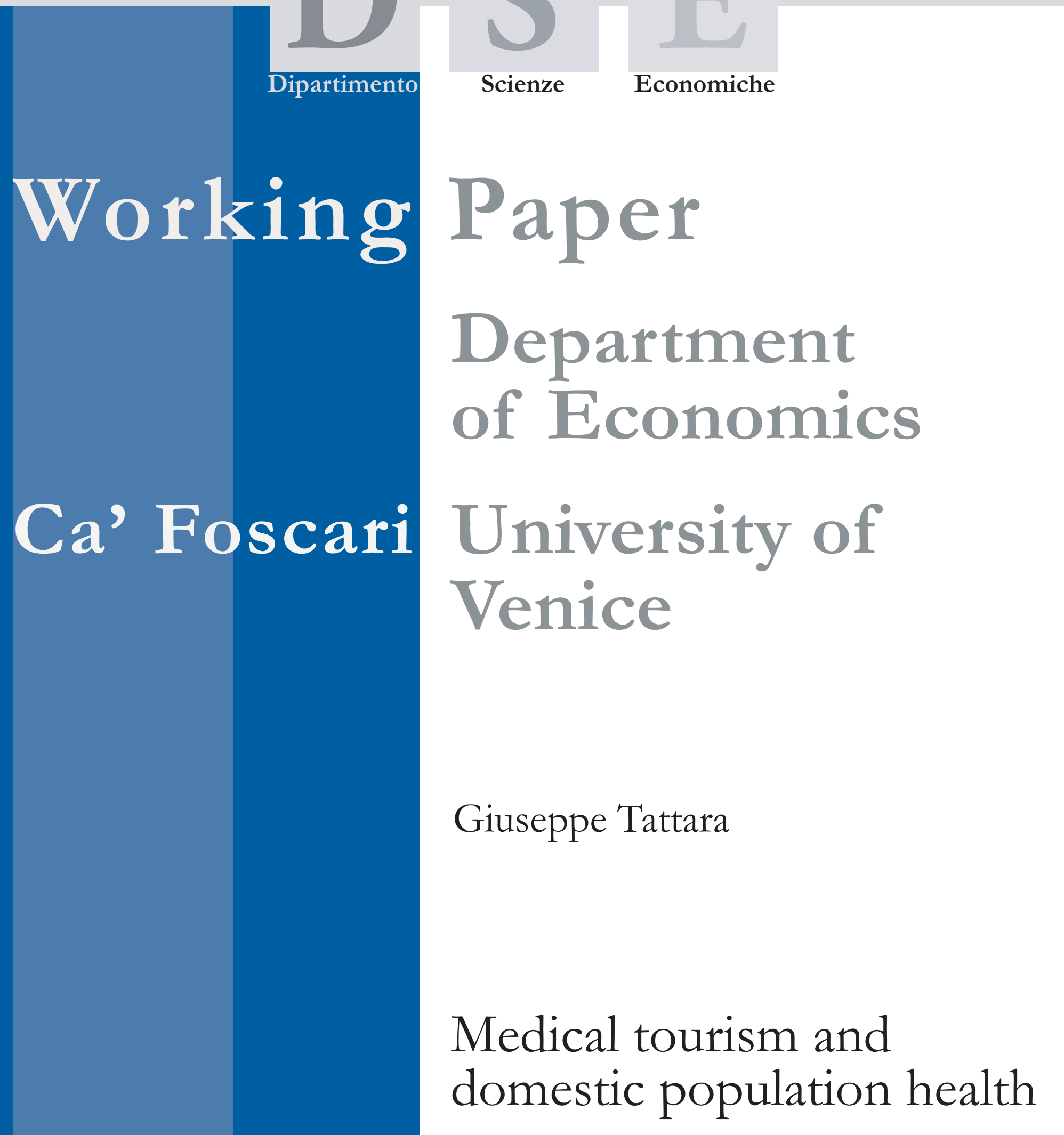




\title{
Medical tourism and domestic population health
}

\author{
Giuseppe Tattara \\ Università Ca’ Foscari Venezia
}

First Draft: January 2010

\begin{abstract}
Medical tourism is a term to describe the rapidly-growing practice of traveling across international borders to obtain health care. Services typically sought by travelers include elective procedures as well as complex specialized surgeries.

Over 50 countries have identified medical tourism as a national industry.

This article deals with the situation of India that is promoting the "high-tech healing" of its private healthcare sector as a tourist attraction. The government hopes to encourage a building trade in medical tourism, selling foreigners the idea of travelling to India for lowcost but world-class medical treatment and India is becoming a "global health destination". This policy however does not develops into better services for the local population as corporale hospitals are clustered in urban settings, their prices are out of reach to the locals and the quota of beds reserved free of charge to the domestic population is often disregarded.
\end{abstract}

\section{Keywords}

Medical tourism, Corporale hospitals, Life expectacy, Economic development, Inequality

\section{JEL Codes}

I12, I18, I38

Address for correspondence:

Giuseppe Tattara

Department of Economics

Ca' Foscari University of Venice Cannaregio 873, Fondamenta S.Giobbe

30121 Venezia - Italy

Phone: (++39) 041234148

Fax: (++39) 0412349176

tattara@unive.it

This Working Paper is published under the auspices of the Department of Economics of the Ca' Foscari University of Venice. Opinions expressed herein are those of the authors and not those of the Department. The Working Paper series is designed to divulge preliminary or incomplete work, circulated to favour discussion and comments. Citation of this paper should consider its provisional character. 


\section{Medical tourism and domestic population health}

Medical tourism is a term initially coined by travel agencies and the mass media to describe the rapidly-growing practice of traveling across international borders to obtain health care. It is not concerned with emergency services for tourists. Medical tourism service typically includes elective procedures as well as complex specialized surgeries such as joint replacement (knee/hip), cardiac surgery, dental surgery, and cosmetic surgeries. However, virtually every type of health care, including psychiatry, alternative treatments, convalescent care and even burial services are available. To these are to be added services provided under the name of reproductive tourism which is the practice of traveling abroad to undergo in-vitro fertilization, surrogate pregnancy and other assisted reproductive technology treatments including the freezing embryos for retroproduction.

Over 50 countries have identified medical tourism as a national industry. Factors that have led to the increasing popularity of medical travel in several countries include the high cost of health care, long wait times for certain procedures, the ease and affordability of international travel, and improvements in both technology and standards of care.

Health care provision, like other area of welfare, has been subject to a process of privatization and contracting out, with the involvement of for-profit corporations. Such processes interact with the process of liberalization at the international level and lead to a growth in the international trading of such services, culminating in a global market in health services (Smith, Blouin, Drager, 2005). While production and distribution of pharmaceuticals already takes place within a global-level market, health service provision is usually deeply embedded in the national structures and medical tourism is a recent example of export of health services through the consumption of services provided domestically for the foreigners.

Medical tourism can be approached as trade in any other commodity. Trade theory assumes, in its most general form that the process of trade liberalization is justified through the overall gains in welfare at the aggregate level, although this can leave some losers on the ground. In principle the revenue provided by medical tourism can be plowed back into health care to benefit the population at large and upgraded facilities catering for foreigners can have a leavening effect throughout the system. However this is not the case as the health market is a segmented market and medical tourism often results in a way of widening the gap between haves and have-not. This trend contrasts the Declaration of Alma Acta adopted at the International Conference on Primary Health Care in 1978 that has expressed the need for urgent action by the world community to protect and promote the health of all the people and make health available to individuals and families at a cost that they can afford. The primary health care approach has since then been accepted by member countries of the World Health Organization as the key to achieving the goal of "Health for All".

The paper reviews the main issues on medical tourism looking at scientific reports, at the websites and health care management magazines and at newspapers. The first paragraph reports some estimates of the growth of medical 
tourism and the economic reasons on the ground of it. The second paragraph examines directly the case of India and shows how health privatization and medical tourism are strictly interlinked and how medical tourism has brought about a transfer of resources in favor of the richest part of the population either domestic or foreign and has led to the neglect of the poorest segments. This situation is likely to appear common to many developing countries deeply involved in medical tourism. The third paragraph looks at some ethical issues around medical tourism for the countries in which it is promoted and concludes.

\section{The growth of medical tourism}

It is estimated that more than 2.9 million of patients enter some foreign country for healthcare services in $2007^{1}$. The total market turnover in the same year is estimated around 30-40 billion US\$.

\section{Table 1. Costs for surgery in US and Asia}

\begin{tabular}{|c|c|c|c|c|c|c|c|c|c|}
\hline \multirow{2}{*}{ Procedure } & \multirow{2}{*}{ US } & \multirow{2}{*}{ India } & \multirow{2}{*}{ Thailand $s$} & \multirow{2}{*}{\multicolumn{2}{|c|}{ SingaporeMalaysia }} & \multicolumn{4}{|c|}{ Percentage of US cost } \\
\hline & & & & & & India & Thailand & Singapol & Malaysia \\
\hline Heart Bypass & 130,000 & 10,000 & 11,000 & 18,500 & 9,000 & $8 \%$ & $8 \%$ & $14 \%$ & $7 \%$ \\
\hline Heart Valve Replacement & 160,000 & 9,000 & 10,000 & 12,500 & 9,000 & $6 \%$ & $6 \%$ & $8 \%$ & $6 \%$ \\
\hline Angioplasty & 57,000 & 11,000 & 13,000 & 13,000 & 11,000 & $19 \%$ & $23 \%$ & $23 \%$ & $19 \%$ \\
\hline Hip Replacement & 43,000 & 9,000 & 12,000 & 12,000 & 10,000 & $21 \%$ & $28 \%$ & $28 \%$ & $23 \%$ \\
\hline Hysterectomy & 20,000 & 3,000 & 4,500 & 6,000 & 3,000 & $15 \%$ & $23 \%$ & $30 \%$ & $15 \%$ \\
\hline Knee Replacement & 40,000 & 8,500 & 10,000 & 13,000 & 8,000 & $21 \%$ & $25 \%$ & $33 \%$ & $20 \%$ \\
\hline Spinal Fusion & 62,000 & 5,500 & 7,000 & 9,000 & 6,000 & $9 \%$ & $11 \%$ & $15 \%$ & $10 \%$ \\
\hline
\end{tabular}

Source: ABILITY Magazine at http://www.abilitymagazine.com/pbb.html.

To compute a ballpark estimate of total costs, add \$5,000 for you and a companion, figuring coach airfare and hotel rooms averaging \$150 per night. For example, a hip replacement in Bangkok, Thailand, would cost about $\$ 17,000$, for an estimated savings of $\$ 26,000$ over treatment in the U.S.

The market is growing very fast, at yearly rates between $15-20 \%$, according to the study published by Deloitte in 2008. This study puts forward a forecast that medical tourism originating in the US could jump by a factor of ten over the next decade. An estimated 750.000 Americans went abroad for health care in 2007 and they are estimated to reach the incredible number of 15 millions by 2017 . Medical tourism for knee/hip replacement has emerged as one of the more widely accepted procedures because of the lower cost and minimal difficulties associated with the traveling to many developing countries in order to have the surgery. Table 1 compares costs for surgery in Asia with US costs (hospital stay only).

S. Murray reports an interview with Renee-Marie Stephano, president of the Florida-based Medical tourism Association in order to assess the future of medical tourism after the Health Reform proposed by the Obama administraton. Mr. Stephano says that the US healthcare reform may not change this and "what we may find is a reduced number of uninsured, but an increased number of

\footnotetext{
${ }^{1}$ Much more conservative estimates have been presented by McKinsey Report on the subject in 2008. On the too restricted specifications used by McKinsey in defining medical tourism see the debate in <treatmentabroad.blogspot.com/2008/05/mackinsey-and-medicaltourism-numbers.html>
} 
underinsured, with some sort of healthcare insurance coverage but when it comes to surgery, the policy will probably only cover a proportion of it”. Even for those with health insurance, deductibles and co-payments for surgery can run to $\$ 12,000$, making a procedure costing, say, $\$ 6,000$ in another country look attractive (Murray, 2009) .

Medical tourism increase has taken great advantage of the accreditation procedures underwent by many hospitals in developing economies that can guarantee foreign consumers a level of confidence that the services provided are comparable to those available in their mother country. For the US Joint Commission International (JCI) fulfills the accreditation role, while in the UK and Hong Kong, the Trent International Accreditation Scheme is a key player. Many international hospitals, as several Hong Kong hospitals, today are having both JCI to cover potential US clientele and Trent for potential British and European clientele. Among countries Thailand is the most favored destination. Thailand has emerged as the largest medical tourism market in Asia for its competent services, low cost with a vacation at a beautiful beach resort as an inviting option. In 2006 Thailand had 4 hospitals accredited JCI. In the same year the country had 1.200.000 incoming medical tourists that generated US\$ 1.1 billion revenue, roughly $9 \%$ of the total revenue generated by tourism in the country; in 2007, 15 million tourists generated around 1.5 billion US\$ revenue. The average cost for treatment was 30\% of the US cost. Medical tourism has been a growing segment of Thailand's tourism and health-care sectors. In 2005 one hospital in Bangkook, the Bumrungrad International Hospital, took in 150.000 treatment seekers from abroad, 55.000 from the US alone, with a 30\% increment from the previous year. A US patient reported to have paid his operation $1 / 8$ of the cost he would have paid in the States. The US consular information sheet gives the Thailand health care system high marks for quality although the World health Organization ranks the country health system at number 47, below the USA's ranking at 37 and the United Kingdom's ranking at 18. This difference provides an idea of the divergence between medical services provided to foreigners and the general medical services availability for local population.

India is the second Asian provider for medical tourism with an inflow of 450.000 tourists in 2007. Indian hospitals have $10 \mathrm{JCI}$ accreditations, and provide health services at an average cost around $20 \%$ of the cost in the US. Singapore in the same year had an incoming tourist flow of 410.000 tourists, its hospitals have 13 JCI accreditations, and the average cost was $35 \%$ of the reported US cost. Recently the government of Singapore has created collaboration between industry and governmental representatives to create a medical hub in the state. Malaysia has 300.000 medical tourists, one hospital with $1 \mathrm{JCl}$ accreditation and is specialized in cosmetic surgery and alternative medicine. The estimated average cost for treatment is less than $25 \%$ of the comparable US cost (table 1).The department of health of the Philippines has produced a medical tourism

\footnotetext{
${ }^{2}$ Several US health insurers have launched medical tourism divisions as part of their health benefit plans. Blue Cross of South Carolina, for example, has brought hospitals in Europe, Asia and Latin America into its network. Attempts have been made in the states of West Virginia and Colorado to introduce legislation that would provide incentives for insurers to incorporate medical tourism in their health benefit plans.
} 
guidebook that is distributed throughout of Europe. Korea has planned new medical institutions for international patients. The Taiwan government has announced a new large-scale project for medical tourism.

From a marketing point of view medical tourism in Asia is a lucrative business. According to a recent report (RNCOS, 2009) revenue from medical tourism from Asia was worth US\$ 3.4 billion in 2007, which is nearly $13 \%$ of the global health tourism market. The report also indicates viable average growth at an annual rate of $18 \%$ between the years $2008-2012^{3}$.

Among non-Asian countries Jordan is an emerging medical tourism destination, with related revenue exceeding 1 billion US\$ in 2007. More 250.000 patients from other countries sought treatment in Jordan that year. This includes an estimated 45.000 Iraquis and approximately 25.000 patients, each from Palestine and Sudan. An estimated 1.800 US citizens, 1.200 UK citizens and 400 Canadians also sought treatment in Jordan that year. Treatment costs can be as low as $25 \%$ of costs in the US. This Kingdom was rated as number one in the region and fifth in the world as a medical tourism hub in a study by the World Bank (Hazaimeh, 2008).

Other countries involved in medical tourism are Hungary that provides reliable dental service and cosmetic surgery. Hungary is mainly used by Europeans, has no accreditations and the cost is estimated about $40-50 \%$ of the US cost. The Gulf States on the whole have 38 JCI accreditations (17 in Saudi Arabia) and have planned a new Health Care City. Mexico has $3 \mathrm{JCI}$ accreditations and its hospitals are used mainly by US patients for dental and cosmetic surgery. The average cost is estimated 25-35\% of the US. Costarica, has 1 JCI accredited hospital, Brazil has $12 \mathrm{JCI}$ accreditations and reliable cosmetic surgery at an average cost of $40-50 \%$ the cost in US. South Africa provides suitable cosmetic surgery, has no JCI accreditations and the cost is estimated $30-40 \%$ of the US cost.

Recently South Korea has entered tha market. The government has launched in 2007 a public-private initiative designed to promote medical tourism called Council for Korea Medicine Overseas Promotion (www.koreahealthtour.co.kr/eng/index.jsp) to develop world-class healthcare infrastructure and to promote Korean healthcare to international patients (Murray, 2009).

\section{Medical tourism in India}

\section{a. an insufficient public health system}

India provides a case fairly typical to many developing countries in that it has a public health care system that is unable to adequately meet demand. Morbidity remains unacceptable high and other health indicators rank India among the most critical situations among developing nations. To day India faces the problem common to all developing countries of building its health care system, which must compete for resources with other basic needs.

\footnotetext{
${ }^{3}<$ asianewsnet.net/news.php?sec $=2$ \&id $=2250>$
} 
The Indian constitution (art. 47) charges the Indian State with "the raising of the level of nutrition and the standard of living of its people and the improvement of public health" (see The Constitutional Framework, ch. 8). The first attempt to put the Constitution into practice in health matter was the National Health Plan that was endorsed by Parliament in 1983 and was committed to providing 'Health for all by the year 2000', through the universal provision of comprehensive primary health care services. In retrospect, it is observed that at the time the Plan was approved, the financial resources and public health administrative capacity were far short of those necessaries to reach such a goal and in subsequent years the idea of a basic national healthcare service free to all has been gradually abandoned. Health care spending progressively grew during the 80s following the growth of the domestic economy, the population increase and stabilized at 6 percent of GDP in the mid-1990s, a level a bit higher than the average of the South East Asian region and higher than the present figure. The major inputs of healthcare expenditure (75\%) came from the private sector that means out of pocket money or user's charges ${ }^{4}$ and not from government expenditure, as in the majority of other countries.

Healthcare spending in India in 2006, was around 4.9 percent of GDP (WHO ${ }^{5}$ ), not particularly high according to the WHO 2008 report and has declined since 1990s. Just after independence the private sector counted for just $8 \%$ of health expenditure (Radwan, 2005). Government health expenditure as well as states health expenditure, have steeply declined since the mid nineties and health expenditure is devoted more and more to birth control ${ }^{6}$; at the same time the share that comes from private expenditure has increased and to day around 80 percent of total spending on healthcare comes from the private sector (WHO, Whosis). The current annual per capita public health expenditure in the country is no more than Rs. 200. In purchasing power terms this corresponds to $109 \$$ compared with an amount three times as bigger for China (WHO, Whosis). Public health care is not only weak but also under-utilized and inefficient and the private sector is quite dominant in the healthcare sector in terms of efficiency and quality of services provided.

For a country of 1.1. billion people India has just 204.000 government run hospitals and clinics (China has 1/3 more) and most of these centers are stuck in the 1960s with limited access to modern equipment, processes and medicine. India has 6 doctors per 10.000 people compared to 14 in China (although China has a bigger population). The number of hospital beds in India is around 1.1 per thousand people, which is significantly lower as compared to the number of beds in many developing economies. China for example has a density of 2.2 (WHO, Whosis).

\footnotetext{
${ }^{4}$ The quota of prepayment schemes is irrelevant.

${ }^{5}$ World Health Organization, Statistical Information System, Whosis

<www.who.int/whosis/whostat/2009/en/index.html>

${ }^{6}$ The share of public financing in total health care is just about 1\% of GDP compared to 2,8 of other developing countries. Health Insurance in India. Dr.Padma Bathia <pitt.edu/ super1/lecture/lec19571/001.htm>

For the decline in public health expenditure and the little public money spent on primary care, Radawam, 2005: 25, 34-35.
} 
India does not have a comprehensive national health scheme and a large number of the poor fall below the poverty line when they are hit by illness. It is estimated that less than $10 \%$ Indians have an health insurance whatsoever ${ }^{7}$.

Indian approach to health is differential in that different provisions are provided for the formal sector (government-non government) and for other organized sectors of the population. All these schemes anyway relate to a small fraction of the working population as in India the workers in the unorganized sector constitute, according to several estimates, the $93 \%$ of the total workforce of the country so that the majority of workers is without social security coverage ${ }^{8}$.

Let us consider the formal sector. For people in the private sector, the Employer Factory Act provides employees working in establishments with 20 or more workers with the Employees' State Insurance (ESI) according to the ESI Act (passed in 1948) ${ }^{9}$. Many contract workers that are entitled to ESI, nonetheless are not covered and controls are difficult; only permanent workers get it. The percentage share of workers covered by ESI is estimated in 2,2\% of the total workforce and $4.8 \%$ of the hired workers. The insurance is paid by the employees and by the government. ESI has its own infrastructure with a number of 143 hospitals. A list of stipulated doctors is provided for check up and workers can be admitted free of cost to the ESI hospitals. The standard of ESI hospitals is very poor; they are limited in number and have a limited territorial diffusion.

Workers in construction are not covered by the Factory Act, neither by ESI. Private firms have often their own health insurance scheme: among those TATA is know for providing a very good health service for its workers but this does not change the overall scenario.

Public sector workers have several schemes. A Central Government Health Scheme, an Employees State Insurance Scheme and other schemes for particular categories (railway workers, post and telecom workers etc.). Government Health Scheme pays the cost of public hospitals. Public hospitals are not free of charge, some of them have a high reputation, but their number is limited and they are unevenly distributed in the territory. Other schemes are available in different states and for specific workers' categories (maternity schemes, various schemes for miners etc.), but the result does not amount to much. A couple of years ago a scheme has been approved to protect people below the poverty line by main hospitalization charges but is still not fully implemented ${ }^{10}$.

Of course Non Government Organizations (NGOs) and community-based organizations provide effective help; but they are limited in number, targeted to

\footnotetext{
${ }^{7}$ This is the most generous estimate. Other estimates restrict coverage to half of it.

${ }^{8}$ Less than $2 \%$ of India's population is currently insured through voluntary medical insurance plans that cover admission to hospital (Mudur, 2003, p. 520).

${ }^{9}$ Details of coverage of different labor regulations are provided in Pais (2008)

${ }^{10}$ On August 15, 2007, Prime Minister Manmohan Singh announced the creation of a new health insurance scheme; the Rashtriya Swasthya Bima Yojana or RSBY. (The scheme was formally launched on October 1, 2007). The objective of RSBY is to protect households below poverty line (BPL) from major health shocks that involve hospitalization. Specifically, BPL families are entitled to more than 700 in-patient procedures with a cost of up to 30,000 rupees per annum for a nominal registration fee of 30 rupees. The scheme is based on private insurance companies and it has just been implemented. It is implemented in phases and very gradually (5 years) and it is estimated to cover 300 million people living below the poverty line.
} 
specific needs or group of people and although they perform rather efficiently, have a limited coverage.

In respect to India China has a comprehensive system of medical insurance that covers to-day more than 1 billion of the country 1.3 billion population. The new scheme, prompted recently by the government, establishes a minimum nationwide safety net which includes the rural medical scheme, the basic medical insurance for urban employees and the unemployed, as well as medical aid for the poor in both rural and urban areas at a moderate cost of around 1,45\$ (10 yuan) per year while the state, provincial, municipal and country government supply another 40 yuan to the fund ${ }^{11}$.

\section{b. a rapid growing private system}

In spite of the poor general health care provided for its citizens, India has a thriving private hospital sector. In the 90s, the deregulation of the Indian economy gave origin to the a general drive towards privatization and medicare sector was not an exception. Cutbacks in public spending on the advice of international agencies, subsidies to the private sector, the growth of the middle class, the increasing number of senior citizens, higher health awareness and rapidly penetrating medical insurance have been accompanied by a dramatic expansion of the private hospital sector. Beds in Indian private hospitals have risen from 29\% of the total in 1973 to $61 \%$ in 1996 and to $64 \%$ in 2001 (Radawan, 2005: 25). On the whole the private sector to-day accounts for more than $80 \%$ of India's healthcare service market (Mapur, 2008; Guruswamy, Mazumdar, Mazumdar, 2008).

Since the beginning of the nineties major economic reforms that are collectively termed as liberalisation in the Indian media, have taken place, resulting in an adverse impact on the health sector. The public health service has suffered a clear decline in investments and expenditures by both central and state governments leading to reduced availability of non-salary inputs like medicines and other medical supplies, diagnostics, and the maintenance of facilities. The outcome has been a large drop in the use of various public health services, while the private sector has expanded rapidly and private hospitals have captured a larger share of the market.

In the pursue of more laissez-faire economic policies, import liberalization has been undertaken with the expectation that it would promote more efficient export production, leading to improved export earning potential which would reduce the current account deficit (closing the gap between imports and exports). Due to the need of foreign exchange the Indian government is willing to offer fiscal and policy incentives to private exporters and to address infrastructure issues that promote the country's growth in exports.

Among the most promising export industries is medical tourism. The National Health Policy (NHP) 2002 develops this concept when it reads "to capitalize on

\footnotetext{
${ }^{11}$ The system is tiered, depending on the location. If patients go to a small hospital or clinic in their local town, the scheme will cover from $70-80 \%$ of their bill. If they go to a county one, the percentage of the cost being covered falls to about $60 \%$. And if they need specialist help in a large modern city hospital, they have to bear most of the cost themselves; the scheme would cover about $30 \%$ of the bill.
} 
the comparative cost advantage enjoyed by domestic health facilities in the secondary and tertiary sector, the policy will encourage the supply of services to patients of foreign origin on payment. The rendering of such services on payment in foreign exchange will be treated as "deemed exports" and will be made eligible for all fiscal incentives extended to export earnings" ${ }^{\prime 2}$. The Tenth Plan goes further ahead in offering more concessions to private hospitals on the assumption that the revenues earned by the industry will strengthen the healthcare provision in the country and be, at the end, favorable to the entire population.

The medical tourism industry is provided with tax concessions as well; the government gives private hospitals treating foreign patients benefits such as lower import duties and an increased rate of depreciation (from 25 per cent to 40 per cent) for life-saving medical equipment. Prime land is often provided at subsidized rates by the local government.

In recent years more and more investors see the health sector as a good proposition, health being the second major profitable trade industry of the country. The health market tourism in India pegged a 30\% growth in 2000 and has been growing at a rate of $15 \%$ for the past five years; according to Deloitte the medical tourism -sector is expected to grow by 30 per cent a year from 2009 to 2015, once the crisis is over (Murray, 2009), a rate of growth much higher then the industrial average.

The Indian success story is the outcome of low cost advantages vis-à-vis quality medical treatment. India is emerging as a major medical tourism market player due to both push and pull factors. Medical tourists are pulled mainly because reduced costs, the availability of latest medical technologies and a growing compliance on international quality standards, as well as the fact that foreigners are less likely to face language barriers in India. Whereas the cost of treatment in other developed nations, especially in the US, UK, is very high, India can provide quality healthcare at very low cost due to the availability of relatively cheaper but quality manpower, low-priced drugs and other infrastructure. Treatment costs in India start at around a tenth of the price of comparable treatment in America or Britain: whereas a liver transplant costs you 500,000 US\$ in USA it can only be done with 40,000 US\$ in India. Further, a heart surgery can be done with 5,0007,000 US\$ in India as against 160,000-60.000 US\$ in USA (table 1). Services provided are largely knee joint replacement, hip replacement, bone marrow transplant, bypass surgery, breasts lump removal, haemorrhoidecotomy, cataract surgery, in vitro fertilization, cosmetic surgery. India has thus become an example of a country that is a net exporter of health services, mainly through the consumption of services in India by foreigners and the off shoring of medical services by more developed countries ${ }^{13}$. The state of India promotes medical

\footnotetext{
12 "Deemed Exports" refers to those transactions in which the goods supplied do not leave the country but benefit for the same advantages as exports (advance licence for intermediate supplì, deemed export drawbacks, refund of terminal excise duties).

13 The market boom within diagnostic services has also seen a remarkable increase in the requirement of outsourcing of radiology services globally. With a pool of well-trained Health Insurance Portability and Accountability Act (HIPAA) compliant radiologists in India, a shortage of radiologists world over, and high-tech infrastructure investments, India is an up-and-coming market for tele-radiology, providing offshore X-ray reporting services to the US, Singapore and the Middle East. Outsourcing teleradiology services to India has proven to be an advantage to small and medium hospitals for countries outside India, which
} 
tourism and the tourism departments of Maharasthra, Kerala and Andhra Pardesh have created their own site to promote the state services. The private travel industry and various tour operators see medical industry as a lucrative business. They offer packages that include airfare, hotel accommodation and surgery expenses with a claim of saving up to $80 \%$ compared to what it costs in the United States. Besides, a new category of visa, "Medical Visa" has been introduced by Ministry of Home Affairs.

Some risks are present nonetheless; India has different viral diseases compared to the American and European continents and exposure to such diseases without having an immunity system built-up can lead to slower recovery rates and complications (Jones, w.d.). Nonetheless, the cheaper cost of essential medical needs and the attention to the urgency of the health care needs is sure to help medical tourism remain a popular choice in the coming days.

India position has been recently strengthened by serious political problems that have affected its main competitor, Thailand, during late 2008. Mass demonstrations and the complete closure of major airports, have made travel to Thailand less appealing than in the past, and the US State Department web site has expressed concerns about the country so that many medical tourists have been redirected towards India.

Tourists are pushed into India because medical care is touching prohibitive levels in the developed countries especially in the US and UK and often long waiting time are requested for undergoing critical medical procedures (Godwin, 2004, p. $3981)^{14}$.

The highly specialized medical industry is a relatively new field which is primarily concerned with new medical appliances, information, communication technologies and only large specialized hospitals run by corporate bodies are the forerunner in these new specializations. Since the profit making capacity of the corporate hospitals is limited by the relatively small size of the domestic consumer market, attracting foreign patients has become a straight way to expand the demand for hospital services. But a step towards modernity seldom reverberates towards domestic population and private hospitals accomplishments towards public health has been greatly defective. The mechanism by which these benefits can turn at the advantage of local population is very debatable and has introduced serious fear of discrimination (George, 1994). In some cases the condition is that corporate hospitals in exchange for the large benefits they get, should provide a stated percentage (30\%) in-patient (IPD) facilities and percentage (40\%) of the out-patient/diagnostic (OPD) services free of cost for people below the poverty line. But corporate hospitals have repeatedly dishonored the conditions for receiving government subsidies by refusing to treat poor patients free of cost - and they have got away without punishment. An inquiry in the early nineties out of 27 hospitals provided free operating

may not have a resident radiologist. According to an estimate, approximately 50 per cent of the 6,000-odd hospitals in the US, still do not have the technology for teleradiology and this represents a huge potential market to be tapped (Pamnani, 2009).

${ }^{14}$ The Institute of Medicine (2004) estimates that about 18.000 Americans die each year from treatable conditions as they cannot afford healthcare. 
department practitioners (OPD) ${ }^{15}$ care up to $15 \%$ of the OPD cases and 12 hospitals gave over $40 \%$ patients free ODP treatment. The majority of hospitals provided less than $10 \%$ of their indoor patients free care and only three claimed to provide free care to more than $20 \%$ of indoor patients. Apollo hospital provides only 2\% patients free care and Batra and Modi Hospital cover 6 and $10 \%$. The proportion of beds fixed for the poor patients also varies. 13 of the 27 hospitals claimed that have they reserved over $20 \%$ beds for the poor while 6 hospitals did not give any information.

Apollo has been the forerunner in health tourism and is the largest of the halfdozen medical corporations in India serving medical tourists. Apollo Hospital in Delhi was allotted 15 acres of land in 1980 by the local government for a figurative rate on the ground that it would provide free treatment to $1 / 3$ of its patients. The Delhi government invested a total of 42 crores in the hospital that was commissioned in 1996. The hospital informed the Committee that 140, instead of 217, ot of 650 beds were for the poor and on average only 20 beds were used at a time for patients who were paying substantial amounts to the hospital (Quadeer, Reddy, 2006, p.11) ${ }^{16}$.

Corporate hospitals have an uneven territorial diffusion, as their location is chosen in order to attract tourists more than to help locals. Apollo hospital in Ahmedabad was set up with the declared intention of attracting non-residents from the world over.

The private sector is strongly present in the urban areas and as a consequence about $75 \%$ of health infrastructure, medical man-power and other health resources are concentrated in urban areas where only $27 \%$ of the population live (Patil, Somasundaram, Goyal, 2002). This contributes significantly to the increase in the urban rural disparity that has characterized the last twenty years of India economic development.

Public and private hospitals operate under different institutional settings. While public health services operate with a set of well-defined rules, the private health sector is completely unregulated - both at the state and professional level. As a consequence there is a growth of unqualified and/or unlicensed practitioners providing care and thus reducing the standard of care to citizens (Ravi, 2000; Rohit, 2001; Bisserbe, 2008, 31). The Clinical Establishment Bill, 2007, attempted to set quality standards for all hospitals, nursing homes and path labs but it is still unclear how the Central government can implement it. The states can either adopt it (as Arunachal Pradesh, Mizoram, Nagaland and Manipur have declared) or do nothing at all (Bisserbe, 2008, 32).

\footnotetext{
${ }^{15}$ Operating Department Practitioners (ODPs) are healthcare professionals working in the United Kingdom. They are mainly employed in surgical operating departments such as Accident \& Emergency, Intensive Care units and the Ambulance Service. ODPs work as a member of a multi-disciplinary team that includes doctors, nurses and support workers.

${ }^{16}$ The equipment in many public hospitals is often obsolete and unusable, the draft policy has admitted, and the buildings are in a dilapidated state. It means that less than $20 \%$ of the population seeks outpatient services and less than $45 \%$ use inpatient treatment in public hospitals-despite the fact that poor people seek private health services at the cost of essential expenditure, such as nutrition. Rohit, 2001.

The authors report that the hospital management argued that the "poor" was not defined and that it was not possible to grant free treatment due to the high cost of drugs.
} 
In principle the private sector is supervised by the National Accreditation Board for Hospitals and Healthcare providers. This is an autonomous body under the Quality Council of India and releases a three-year accreditation certificate. Till September 2008 only 20 hospitals have been accredited and 54 applications were pending. Some have been rejected. One of India's famous hospitals, the Apollo's Delhi hospital, was denied accreditation, as the out-patient department was not up to the mark.

Recently Apollo is aggressively moving into medical outsourcing. It provides overnight computer services for U.S. insurance companies and hospitals as well as working with big pharmaceutical corporations with drug trials. Since 2004 it has been working with Britain's National Health Service as a subcontractor, to do operations and medical tests for patients at a fraction of the cost in Britain for either government or private care. At the same time Apollo is expanding abroad via outward foreign direct investment: Apollo plans to build several new hospitals in Bangladesh, Dubai, Sri Lanka, Africa $<$ www.apollohospdelhi.com/apollo-group/chairmans-profile.html $>$ Hyderabad has CDR group of hospitals, CDR Hearth Institute, Medwin Hospitals, Apollo Hospitals etc. (www.tourismofindia.com/exi/Hitlist.htm).

In Delhi the Escort center is a favorite destination from patients from abroad. With Bupa (British United Provident Association) recognition patients are coming for treatment from the UK. About 1000 patients from abroad are treated in Escort on an annual basis. Rockland hospital in Delhi opened in 2004 and has a wind dedicated to medical tourism.

Most of the major metropolitan cities, like Delhi, Bombay, Calcutta, Chennai, Hyderabad have shown tremendous growth in corporate hospitals with multispecility care. Major hospitals in these cities have recorded a $12 \%$ of patients flow from foreign countries.

Chennai has a number of hospitals in the list of the Ministry of Tourism for promoting medical care. The most relevant are the Apollo institute for CardioValscular disease, the Madras Medical Mission, the Institute of Cardio Valscular Diseases, the Ramachandra Educational and Health Trust, the Hearth Institute, the Vijaya Health Centre etc (Reddy, 2009, p. 9).

The last issue of medical organization is represented by medi-cities. All medicities have been explicitly projected as a foreign exchange earners. A medi-city is an integrated township of super speciality hospitals, diagnostic centers, medical colleges, research and development and other facilities (shopping mall, hotels etc etc). In Gurgaon Medanta medi-city is located on 43 acres, close to New Delhi and has 45 operating theatres, 1250 beds and over 350 critical care beds. In Pune the Aditya Birla Memorial Medicity is located in 13 acres, has 13 operating theatres, 125 intensive care beds. A medi-city is to be planned in Bangalore, Jaipur and in Pune, Shillong, Thiruvanthanapuram and Mangalore. In Jaipur the task to build a new medi-city has been assigned to the Anil Dhirubhai Ambani Group and the project is specially targeted to medical tourists. The south Indian city of Chennai has been declared India's Health Capital, as it nets in $45 \%$ of health tourists from abroad and $30-40 \%$ of domestic health tourists.

Medi-city is a project where most clearly one can touch the dichotomy between efficiency and segregation from the surrounding population. 


\section{c. negative consequences of privatization and medical tourism}

The first negative consequence of the privatization policy is for doctors. Even now, most of the professionals in the private institutes have migrated from government institutions and will remain available only for the foreign tourists and Indian elites. In Thailand, the state that attracts the largest number of medical tourists in 2008 it was stated that, "doctors in Thailand have become so busy with foreigners that Thai patients are having trouble getting care".

In India private industry gets a pool of medical professionals who train in public institutions for a very modest fees and then move to work in private hospitals - an internal brain drain, and an indirect subsidy for the private sector of an estimated Rs 500 crore per year. This is a winning ticket for the corporate medical sector and for a section of medical professionals in the country.

Indian private health care costs are likely to hike up as the number of medical tourists increases and quality health care, that was already very expensive, will become unaffordable top the common person. At present seventy per cent of the rural population does not have access to proper health care and many choose to not seek any treatment at all as the cost for private practitioners are far beyond their financial possibilities. On the other side, however, the Indian Ministry of Health is accrediting hospitals and recommending prices for their services to guarantee service quality for the medical tourism and not to the local population. Another serious consequence of the increasing number of medical tourists is the dump their medical waste in areas where 'ignorant' citizens live as no proper medical waste management system is in place. As in many developing countries, waste is not separated: from reception-area trash to surgery room waste - all is burnt in incinerators or dumped into rivers or the sea. These external costs are not included at all in the overall running costs, so the businesses are running very cost efficiently!

Also, the trade in organs is a serious problem. It is an existing problem but it might get even worse with increasing Medical tourism. 96\% of people surveyed had sold their organs (mostly kidneys) for an average of US\$1,070, and paid off their debts with that money. The majority of those organs are not used in India though where a long waiting list for organ transplantation exists. Despite the 1994 Human Organs Transplant Act which criminalises organ sales, due to inefficient control, corruption and better prices paid abroad, illegal trafficking of organs is common.

\section{Conclusions}

The authoritative forerunner of health privatization policy is probably the World Bank 1987 document titled "Financing health services in developing countries"17. International organizations have most influence in developing countries and the World Bank study has recommended to increase the amounts paid by patients, to develop private health insurance mechanisms (that requires a dismantling of state supported health services because if free of cost health services are available

\footnotetext{
17 These recommendations have been subsequently fine tuned by the World Bank Development report "Investing in Health" (1993).
} 
there is no ground for private insurance) and to expand the participation of the private sector (Globalisation and Health, p. 18).

While the World Bank has promoted the development of the private sector, trade negotiations through the WTO aimed at the removal of barriers to the entry of foreign providers. Developing countries are particularly fragile under this respect as the welfare state is not jet built and it can be shaped in a neo-liberal fashion from the beginning, with emphasis on providing and eventual safety net for the poor rather than the universal welfare states common in developed countries. In almost every developing country where these prescriptions have been followed the health condition has deteriorated. In face of such evidence the World Bank has been forced to modify its early recommendations but the changes in World Bank thinking are still inadequate to provide a reverse of the negative trend ${ }^{18}$.

A well documented and clear example of negative consequences on people health of the withdrawal of the role of the state form the medical sector is provided by the evidence available from many socialist and post-socialist countries undergoing economic restructuring. China's deregulation of the health sector in the 1980s, and the subsequent steep increases in reliance on out-ofpocket spending, is a case in point and a warning to the rest of the world. A spectacular deterioration of health-care provision and social protection, particularly in rural areas, led to a marked slowdown in the increase in life expectancy. This caused China to re-examine its policies and reassert the Government's leadership role - a reexamination that is far from over. A similar scenario of disengagement was observed in Russia in the last two decades ${ }^{19}$ and in many of the countries of central and Eastern Europe and the Commonwealth of Independent States. In the early 1990s, public expenditure on health declined to levels that made administering a basic system virtually impossible. This contributed to a major decline in life expectancy. Catastrophic health spending became a major cause of poverty ${ }^{20}$. More recently, funding levels have stabilized or even increased, but significant improvements in health outcomes have not followed and socioeconomic inequalities in health and health-care access have

\footnotetext{
18 The WHO's Commission on the Social Determinants of Health (CSDH) released its findings at the end of August 2008 after a three-year programme of research and analysis. It found that the "toxic combination of bad policies, economics, and politics is, in large measure responsible for the fact that a majority of people in the world do not enjoy the good health that is biologically possible". The commission saves overt criticism of the World Bank and IMF for its discussion of global governance, where it critiques the lack of democracy in the institutions; but the report also faults the lack of investment in universal health care systems and primary health care. As a result of reforms pushed by "a combination of international agencies, commercial actors, and medical groups whose power they enhance" the report finds "on the one hand an increasing commercialisation of health care, and on the other, a medical and technical focus in analysis and action that have undermined the development of comprehensive primary health-care systems that could address the inequity in social determinants of health” (WHO, 2008a).

For a criticism to both the WHO and the CSDH approach see Banerji, 2006.

${ }^{19}$ See Field, Kotz and Bukhman, 2000.

${ }^{20}$ In the Philippines health expenditure was cut from 3.5\% of GDP in 1985 to 2\% in 1993, in Mexico from 4,7\% to 2,7\% in a decade. Declining are also China and Vietnam. As a consequence of such a policy and of the growing world population, the gap in infant mortality rate (under 5 death rate) between rich countries and the poor has widened after 1978 from a ratio of 7.8 to 12.5 in 1998.
} 
been rising. Medical tourism in poor countries is strictly interlinked with the health privatization process and the ability to provide excellent treatment to some sectors of the population, not caring for the performance of the whole system.

India is fairly typical of many developing countries in that it has a public health care system that is free at the point of use $\mathrm{e}^{21}$ but is unable to meet the demand for its services. However the country is atypical in that it has a thriving private hospital sector. Cutbacks in public spending on the advice of international agencies, the granting of subsidies to the private sector, an the growth of the middle class have been accompanied by a dramatic expansion in the private hospital sector. In India health tourism is actively promoted and several hospitals end up exclusively or predominantly serving wealthy foreigners and may set in train an "internal brain drain" from the public to the private sector. In many circumstances government is not able to take action to capture the advantages of trade in health care for the poor by regulating for reserved or subsidized beds for them.

Medical tourism is demanding more subsidies and incentives from the government with the argument that it earns high revenues and foreign currencies and provides direct compensation for poor Indians that are treated free of charge. This compensation is however not warranted as lobbies set up by the private hospitals are too powerful to be forced and do not respect the rules settled by the government. But subsidizing the corporate sector reduces even more the already limited health service resources for the poor. The questions that immediately come to mind are: how could a country like India dare to promote medical tourism when the basic healthcare needs of the majority of its citizens are not even met? why should medical tourists benefit from Indian private structures subsidized by the Indian taxpayer while the domestic population lacks its basic needs?

Current process of change in India illustrates a particular problem for developing countries where markets in health care are encouraged. This relates to the uneven economic development that often takes place in such countries and corporate hospitals may end up exclusively or predominantly serving the wealthy foreigners and may set in train an "internal brain drain" from the public to the private sector $^{22}$.

The current process of reform in health systems, when combined with trade liberalization processes at the international level, represents profound choices that affect the delivery of health services over time. Given these trends it is important that policy analysts continue to assert the importance of public provision for pursuing the social policy goal stated in the Alma Atta declaration and that such policy provision is extended.

\section{References}

\footnotetext{
${ }^{21}$ Ilused to be completely free, but now a limited payment is required

22 For example the latest WHO report (2008b) provides concerns about those systems where a laissez faire approach to government has allowed unregulated commercialization of health to flourish (p. Xiii) but nonetheless advocates the existence of pluralistic health systems operating in a globalized context (p. XV)
} 
Banerji Debabar. 2006. Serious crisis in the practice of international health by the World Health Organization: the Commission on Social Determinants of Health. International Journal of Health Services.36 (4): 637-50

Bennett Sara, Dakpallah George, Garner, Paul, Gilson Lucy, Nittayaramphong Nitta, Zurita Beatriz, Zwi Antony. 1994. Carrot and stick: state mechanism to influence private provider behaviour. Health Policy and Planning 9(1): 1-13

Buse Ken. 1994. The World Bank. Health Policy and Planning 9(1): 95-99

Deloitte, 2008. Medical tourism. Deloitte Center for Health Solutions.

Field Mark G., Kotz M. David, Bukhman Gene, 2000. Neoliberal Economic Policy, "State Desertion” and the Russian Health Crisis, In Kim J.Y, Millen, J.V Irwin A. Gershman J, eds. Dying for Growth. Global inequality and the health of the poor. Commom Courage Press. Cambridge MA.: 155-173.

Gorge Thomas.1994. Distorted Perspective on Health Care. Economic and Political Weekly. 29(30) Jul. 23: 1913

Guruswamy M., Mazumdar Sumit, Mazumdar Papiya. 2008. Public Financing of Health Services in India: An Analysis of Central and State Government Expenditure, Journal of Health Management. 10(1): 49-85

Hazaimeh Hani. 2008. Jordan tops region as medical tourism hub. Jordan Times, Monday, September 8

Holden Chris. 2005. Privatization and Trade in Health Services: A Review of the Evidence. International Journal of Health Services, 35 (4): 675-698

Jones Ronn. w.d. Medical Tourism. Risks and Rewards.

Mudur Ganapati. 2003. India plans to expand private sector. British Medical Journal. March 8; 326: 520

Murray Sarah. 2009. Travel sickness. Financial Times, December 7th

Pais Jesim. 2008. Effectiveness of Labour Regulations in Indian Industry. In T.S. Papola (ed.) Labour Regulation in Indian Industry V.4, Bookwell Publishers, Delhi.

Pamnani Divya. 2009. Spinning the Money. Imaging 2009, <www.expresshealthcare.in/inimaging2009/inimaging200902.shtml>

Patil Ashok Vikhe, Somasundaram, K. V., Goyal, R. C.. 2002. Current Health Scenario. Australian Journal of Rural Health, 10(2), April.

Qadeer Imrana, Reddy Sunita. 2006. Medical Care in the Shadow of Public Private Partnership. Social Scientist. 34(9-10): 4-20

Ramirez De Arellano Annette B. 2007. Patients without borders: the emergence of medical tourism. International Journal of Health Services. 37(1): 193-196.

Ravi Duggal. 2000. The private health sector in India: Nature, Trends and a Critique, Centre for Enquiry into Health and Allied Themes

$<$ http://www.cehat.org/> 
Reddy Sunita. 2009. Emergence of medical tourism in India. Conference on Challenges innHuman development in India January 24-28, CDS, Trivandrum

RNCOS. 2009. Asian Medical tourism Analysis (2008-2012).

$<$ www.marketresearch.com/product/display.asp?productid=2290189

Sharma Rohit. 2001. India proposes new health policy but admits flaws. British Medical Journal 323, 15 September: 592

Smith Richard, Blouin Cahntal, Drager Nick. 2005. Trade in Health services and the Cats: introduction and summary In International Trade in health services and the Gats. The World Bank.Whashington D.C.

Timmermans Karin. 2004. Developing countries and trade in health services: which way is forwarded? International Journal of Health Services. 34(3): 453466.

World Bank. 1993. Development report. "Investing in Health".

World Health Organization. 2008a. Commission on Social Determinants of Health, Final Report Closing the gap in a generation. Health equity through action on the social determinants of health. Geneva.

World Health Organization. 2008b. The World Health Report 2008.Primary Health Care (Now More Than Ever). World Health Organization. 